\title{
Prospects of Promoting NTFPs for Livelihood Improvement
}

\author{
Biraj Pyakurel $^{1}$ \\ Email : itsmebeeraz@hotmail.com
}

\begin{abstract}
This research entitled, "Prospects of Promoting NTFPs for Livelihood Improvement" was carried out in Habeli Community Forest of Nuwakot district with the specific objectives of assessing the status of NTFPs in the study area, studying the local people's knowledge about NTFPs, their attitude towards collection and domestication, assessing the role of NTFPS to household economy and existing market system of NTFPs. Altogether 30 households were sampled to carry out the research and the information regarding biophysical and socio economic condition, perception towards NTFPs and their domestication were collected through various PRA and RRA tools like Household Survey, Group Discussion, and Key Informant Survey (KIS). People were generally familiar with the NTFPs and their importance and were slowly heading towards NTFPs domestication although on a small scale. The respondents have been utilizing their agricultural land to grow NTFPs like Asparagus racemosus, Emblica officinalisand other species like Dendrocalamus strictusand Arundinaria intermediathat were grown naturally on the farmlands and were also willing to domesticate more NTFPs having higher market value such as Swertiachirayita in the upcoming days. Altogether of 34 NTFPs of 28 different families were documented in the study area where most of them were in their wild stage. The C.F has the immense opportunity of promoting NTFPs in future which is at the rapid conservation stage right now. The geographical and climatic conditions are also favorable to grow NTFPs that may lead towards the initiation of forest based small scale enterprise that can eventually generate employment and income.NTFPs promotion has become essential in all parts of the country so research on this subject matter can create a milestone in the economic upliftment of the country. The future research on promotion of NTFPS, local manufacturing of NTFPS, distribution ecology and reproductive biology of NTFPS also has the great potentiality.
\end{abstract}

Key Words:NTFPs, Livelihood, Collection, Promotion, Prospects, Domestication

${ }^{1}$ Kathmandu Forestry College 


\section{Background:}

In spite of occupying only $0.03 \%$ of the global landmass, the diverse geography and climate of Nepal has rendered it a unique land of Non timber Forest Products (NTFPs) along with other natural resources. About 7000 vascular plants have been reported in the country so far, out of which approximately 700 are of medicinal value, of which 238 are in active use and 100 are traded (Subedi 2003). NTFPs have been welfare, subsistence or livelihood commodity since long; these are traditional source of food, fiber, medicine, etc. In some rural hilly areas, they contribute up to $50 \%$ of total annual family income. NTFPs subsector in Nepal contributes about $5 \%$ of national GDP out of total estimation of about 15 $\%$ from the whole forestry sector (almost 1/3). More than 100 types of plant species are harvested from the wild and traded to international market mostly to India; $95 \%$ of the NTFPs are collected from the wild and $90 \%$ are exported to India in raw form.

NTFPs have the potential for contributing to the local economy, to meet subsistence needs and to improve natural resource management systems, leading to the conservation of a given ecosystem and its biodiversity. But the government program is focused more on timber and fuel-wood production. Commercial production of NTFPs has been overlooked. There is no any economic mapping and inventory of NTFPs. There have been so many indigenous practices of growing medicinal and aromatic and other types of NTFPs on farmland for subsistence local use, although government has not any such program that can promote these knowledge and skills for commercial production.

Evidences also indicate that NTFPs could be domesticated as other food crops. But surprisingly many of the most often used annual and perennial NTFPs remain neglected for domestication till date (Pandit, 2001). Domestication of NTFPs in Nepal is in slow pace and not extensive. People are generally not very much willing to cultivate NTFPs in the cultivated land. No research has been done so far why people are unwilling to domestication as NTFPs has high potential in fulfilling the household needs. Therefore this research tries to explore the factors and causes influencing the domestication of NTFPs species.

NTFPs have become the major source of livelihood of farmers in the mid-hills of Nepal and continue to be in future also as there lacks off-farm employment opportunity. But the natural resource base of NTFPs has been decreasing over time with increased population and high demand for the products. This increased demand due to high commercial value of certain species has lured the poor people to exploit the resource base in an unsustainable manner. Thus many NTFPs have reached the verge of extinction due to overexploitation of the natural resource base. Overexploitation is geared by the high economic value of these NTFPs. Unless there is a clear-cut property rights, the chances of conservation is low.

Another and equally important problem associated with promotion of NTFPs is the insecure and seasonal fluctuation in market price of the product. Trader-controlled market and weak bargaining power of the farmers are also domestication related problem. So there is an urgent need to explore the existing markets and marketing systems of NTFPs. 
As there is a lack of any reliable information on NTFP collection, domestication and trading at micro level, any analysis based on assumptions and sketchy information can't be considered reliable. Thus this research makes an attempt to generate much needed information related with NTFPs and its promotion in the study area.

\section{Study Area:}

Out of 314 community forest in the district, Habeli Community Forest was selected as a study area located in Okarpauwa-4, Nuwakot having a total area of 151.4 hector just $25 \mathrm{~km}$ away from Balaju, Kathmandu. It lies at an elevation of $1300 \mathrm{~m}-1900 \mathrm{~m}$ above the sea level. The total number of households in the C.F is 158 which possess a total population of 948 including 463 males and 485 females. The forest user group committee consists of 11 members with an active participation of 6 female members. Mainly Tamang community is

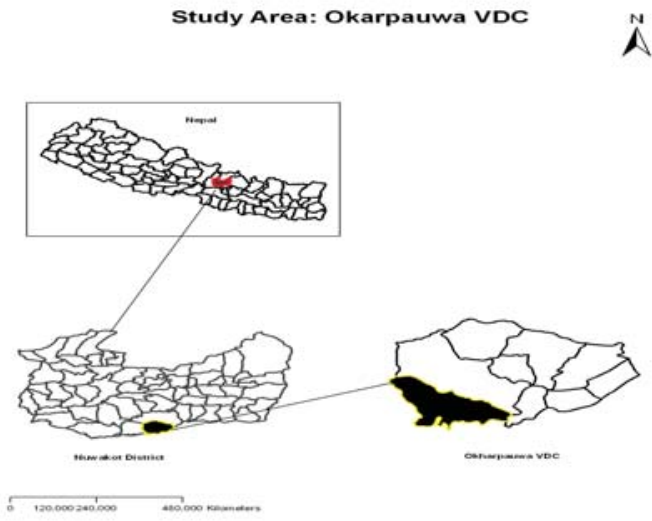

Figure 1: Map showing the study area residing in the area with very few Newar and Kami households. Most of the users of the C.F are mainly involved in agriculture. It is a plantation forest with major tree species of Khottesalla, Gobresalla, Dhupi, Uttis, Laligurans, Angerietc while the major NTFPs found in the C.F are Dhasingare, Chiraito, Laud salla, Ainselu, Chuttro, Sugandawal, Naghbeli, Titepati, etc

\section{METHODOLOGY}

Data were collected from both primary and secondary sources. Primary sources were collected through a survey of 30 household, traders' survey, field observation, key informant interview and group discussions held with farmers as well as traders at local level. Simple random sampling was used for household survey which covered a wide array of matters related to household characteristics, occurrence of NTFPs species, preference and willingness of farmers to grow NTFPs and reasons for not domesticating, preferred and high value NTFPs in privately owned farmlands. While secondary data were extracted with the help of published and unpublished documents and relevant literature regarding NTFPs and its prospects of promotion which was collected mainly to supplement primary data and for some new information as well. These data were collected from DFO Nuwakot, Kakani Range Post, Constitution and Operational Plan of Community Forestry, ICIMOD, IUCN, LFP, ANSAB, FECOFUN, KAFCOL library and various related websites. 


\section{RESULT AND DISCUSSION}

\section{NTFPs Collection and Marketing:}

\section{Common NTFPs found in the Study area:}

Based on the direct field observation, group discussion with villagers and household survey; it was revealed that a number of NTFPs can be found in the CF as well as in the farmlands. The common NTFPs are Kurilo, Chiraito, Dhasingare, Bans and Nigalo. The detailed list of NTFPS found is given below:

Table 1: List of NTFPs found in the study area

\begin{tabular}{|c|c|c|c|c|}
\hline S.N & Local name & Scientific name & Family & Uses \\
\hline 1 & Aakashbeli & Cuscutare flexa & Convolvulaceae & $\begin{array}{l}\text { Medicine for jaundice, } \\
\text { headache, rheumatism. }\end{array}$ \\
\hline 2 & Ainselu & Rubuse llipticus & Rosaceae & $\begin{array}{l}\text { Fruits as food and } \\
\text { medicine }\end{array}$ \\
\hline 3 & Alainchi & Amomums ubalatum & Zingiberaceae & Seeds in neuralgia \\
\hline 4 & Amala & Emblica officinalis & Euphorbiaceae & $\begin{array}{l}\text { Seeds/ fresh fruits for } \\
\text { cooling, diuretic and } \\
\text { laxative }\end{array}$ \\
\hline 5 & Amliso & Thysanolaena maxima & Gramineae & Making brooms. \\
\hline 6 & Asuro & Adhatodav asica & Acanthaceae & $\begin{array}{l}\text { Leaves to cure cough, } \\
\text { chronic bronchitis and } \\
\text { asthma }\end{array}$ \\
\hline 7 & Ban lasun & Lilium nepalense & Liliaceae & Edible as tonic. \\
\hline 8 & Bans & Dendrocalamus strictus & Gramineae & For baskets, mats. \\
\hline 9 & Bish & Aconitum ferox & Ranunculaceae & $\begin{array}{l}\text { Roots valued for } \\
\text { leprosy. }\end{array}$ \\
\hline 10 & Bojo & Acorus calamus & Araceae & $\begin{array}{l}\text { Roots for antispasmodic } \\
\text { use. }\end{array}$ \\
\hline 11 & Chiraito & Swertia chirayita & Gentianaceae & $\begin{array}{l}\text { Whole plants in } \\
\text { antimalarial and } \\
\text { antidiarrhoetic use. }\end{array}$ \\
\hline 12 & Chutro & Berberis aristata & Barberidaceae & $\begin{array}{l}\text { Woods and root in skin } \\
\text { disease and jaundice. }\end{array}$ \\
\hline 13 & Dhasingare & Gaultheria fragrantissima & Ericaceae & $\begin{array}{l}\text { Oil as mouthwash and } \\
\text { toothpaste. }\end{array}$ \\
\hline 14 & Eklebir & Lobelia pyramidalis & Campanulaceae & $\begin{array}{l}\text { Leaves to cure asthma, } \\
\text { fever }\end{array}$ \\
\hline 15 & Ghiukumari & Aloe vera & Liliceae & $\begin{array}{l}\text { Plants for rectural } \\
\text { fissures, piles. }\end{array}$ \\
\hline 16 & Gujargano & Cissampelos pareira & Menispermaceae & $\begin{array}{l}\text { Rhizome to cure skin } \\
\text { eruption, itching and } \\
\text { ulcers }\end{array}$ \\
\hline 17 & Jhau & Parmeliane palensis & Parmeliaceae & Plants for epilepsy \\
\hline
\end{tabular}




\begin{tabular}{|c|c|c|c|c|}
\hline 18 & Jiwanti & Dendrobium macraei & Orchidaceae & $\begin{array}{l}\text { Plants in rheumatism } \\
\text { and tonics }\end{array}$ \\
\hline 19 & Kafal & Myricae sculenta & Myricaceae & $\begin{array}{l}\text { Edible as fruits and } \\
\text { barks in tanning, dyes. }\end{array}$ \\
\hline 20 & Kurilo & Asparagus racemosus & Liliaceae & Roots as refrigerant \\
\hline 21 & Kutki & Picrorhizas crophulariaefolia & Scrophulariaceae & $\begin{array}{l}\text { Plants in cholagogue } \\
\text { and dyspepsia }\end{array}$ \\
\hline 22 & Laligurans & Rhododendron arboreum & Ericaceae & Flower to cure cough \\
\hline 23 & Majitho & Rubia manjith & Rubiaceae & Roots as tonic. \\
\hline 24 & Nagbeli & Lycopodium clavatum & Lycopodiaceae & $\begin{array}{l}\text { Spore in blood and } \\
\text { lungs infection }\end{array}$ \\
\hline 25 & Neem & Azadirachta indica & Meliaceae & Plants in skin disease \\
\hline 26 & Nigalo & Arundinaria intermedia & Gramineae & $\begin{array}{l}\text { For baskets, } \\
\text { handicrafts. }\end{array}$ \\
\hline 27 & Nundhiki & Osyris wightiana & Santalaceae & Bark to stop bleeding \\
\hline 28 & Okhar & Juglans regia & Juglandaceae & $\begin{array}{l}\text { Bark as hair growth } \\
\text { tonic. }\end{array}$ \\
\hline 29 & Pakhanved & Bergenia ciliata & Saxifragaceae & $\begin{array}{l}\text { Rhizomes and roots in } \\
\text { dissolving kidney stone }\end{array}$ \\
\hline 30 & Rani sallo & Pinus roxburghii & Pinaceae & Resin for paints, soaps \\
\hline 31 & Sugandhwal & Valeriana jatamansii & Valerianaceae & $\begin{array}{l}\text { Oil as perfumes and } \\
\text { skin diseases. }\end{array}$ \\
\hline 32 & Talispatra & Taxusw allichaina & Taxaceae & Wood as an incense \\
\hline 33 & Tejpat & Cinnamomum tamala & Lauraceae & $\begin{array}{l}\text { Leaves and barks as } \\
\text { spice }\end{array}$ \\
\hline 34 & Titepati & Artemisia vulgaris & Compositae & $\begin{array}{l}\text { Plants to cure asthma } \\
\text { and itching }\end{array}$ \\
\hline
\end{tabular}

Source: Field Survey, 2009

\section{NTFPs Collection:}

Having a great potentiality of NTFPs in the future, collection of NTFPs is totally banned in the C.F from last five years. As a result, the amount of NTFPs is profusely rising. The users don't collect NTFPs from the C.F. Only naturally grown NTFPs like Dendrocalamus strictus, Thysanolaena maxima and Arundinaria intermedia are collected by the farmers and sold in small scale. In the study area, since 2007 Kaulee.V has been helping the local people by providing technical and financial support to practice the different agro forestry techniques minimizing the form of traditional terrace farming which forwards to the higher production of crops that gives more economic benefit from the same size of land in reduced time and effort. At present, Kaulee.V emphasizes on developing public relations by providing different information as well as distribution of seedlings of various agro horticultural crops with few NTFPs like Asparagus racemosus,Emblica officinalis, Azadirachta indica etc. These NTFPs are in its initial stage and surely increase in the upcoming days, NTFP domestication and collection will gain the pace after these NTFPs will grown and provide the yield. 


\section{NTFPs Marketing}

NTFP Marketing in Nuwakot district is quite significant. Total of thirty- five major NTFPs are being traded from the district that have contributed a lot in the overall economic upliftment of the rural people. Among them, Arundinaria intermedia is the major NTFP of the district. Likewise, the users of adjusting community forest collect and sale NTFPs like Asparagus racemosus and Swertia chirayita in large scale which have benefited in their livelihood improvement. But in the study area, NTFP collection inside community forest is not being observed due to the emphasis given for the conservation of NTFPs. Thus the availability of NTFPs is rising day by day. In the future, when the collection and sale of NTFPs will be open, the users may also be benefited by NTFPs collection. Till date only Dendrocalamus strictus, Thysanolaena maxima and Arundinaria intermedia available in their own farmland have been used for the personal use in household level consumption. People make different products like doko,bhakari, nanglo, kucho, mats and sell them to the local people in small scale. These products are also taken to the near market Ranipawa and even to Balaju for the purpose of sell if exceeds the demand of local area. Thus, there is higher probability of NTFP marketing in the study area in coming days ahead.

\section{Role of NTFPs in Household Economy:}

NTFP has played a significant role in the contribution of household economies in the areas where marketing opportunities and transportation facilities are available. NTFP has mostly helped in providing important labour opportunities and supplementary income which make easier for the local people to fulfill their basic needs. In the study area, local people are selling furniture, broom, mats, handicrafts etc made from Dendrocalamus strictus, Thysanolaena maxima and Arundinaria intermedia in the village and near market by which they are fulfilling their basic needs. If the promotion of NTFP is made in the vigorous scale, there is the possibility of establishment of NTFP based industries that will create further employment and income generating opportunities. Local people will not take the initiative towards sustainable use and management of NTFPs until and unless they are assured about the personal benefits they acquire.

\section{NTFPs Domestication:}

The domestication of NTFPs simply involves the growing of NTFP on the private lands. NTFPs domestication is conceptualized as a process of selecting NTFPs of commercial value and the management in order to improve their yields and quality so that farmer would be able to have a good amount of income.

In the study area, NTFPs like Dendrocalamus strictus and Arundinaria intermedia are grown naturally in the farmlands. While some of the NTFPs like Asparagus racemosus, Rubus ellipticus, Emblica officinalis, and Aloe vera are being domesticated by the farmers but are in initial stage. Most of the farmers cultivate Strawberry in their farmlands rather than 
NTFPs. The question arises as to why farmers are not cultivating NTFPs at relatively large scale like Strawberry. The reasons for not growing of NTFPs may be due to the lack of much awareness of the prices of NTFPs, scarcity of the land holding, constraints regarding scientific and technical knowledge of collection, harvesting farmers may not be sure that they will be able to sell the products in time. Therefore it is sensible to know the existing and possible problem constraining the domestication of NTFPs.

Occurrence of NTFPs in the farmlands: During the field survey, 88 percent of the farmers have NTFPs either grown naturally or planted in their farmlands. On the other hand, 12 percent were engaged only in producing agricultural crops. Some observed NTFPs on the farmlands are:

\section{Clump or Bush Species:Dendrocalamus} strictus, Arundinaria intermedia and Thysanolaena maxima.

Tree Species: Emblica officinalis, Azadirachta indica and Cinnamomum tamala.

MAPs: Asparagus racemosus, Aloe vera, Rubus ellipticus and Amomum subalatum.

\section{Perception of Profitability:}

As recent studies on NTFPs suggest that they may be more profitable than other field crops, all of the respondents were asked whether or not they consider NTFPs as more profitable than other traditional field crops. Out of which, 53\% claimed NTFPs are more profitable than other field crops. Likewise $30 \%$ were against this fact and $17 \%$ were unable to make any comments on it.

\section{Farmers' Willingness to Plant NTFPs:}

Besides farmers' perception, their willingness to grow NTFPs in their private lands may be influenced by several other factors such as landholding size, human power, marketing opportunity etc. As shown in Table 6, most of the respondents
Occurence of NTFPs in the farmlands

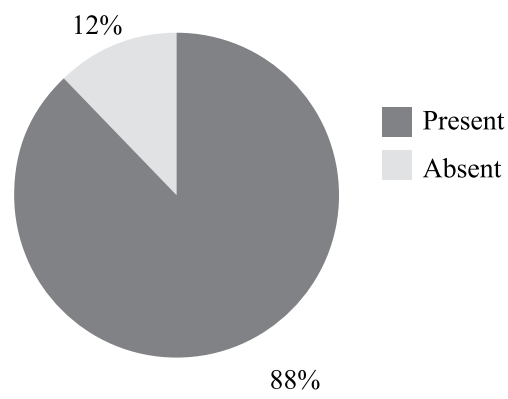

Figure 2: Occurence of NTFPs in the farmlands of the respondents
Perception of Profitability from NTFPs

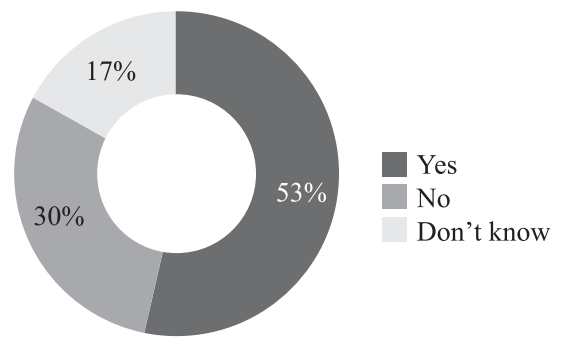

Figure 3: Perception of profitability from NTFPS

Farmers' Willingness to plant NTFPs

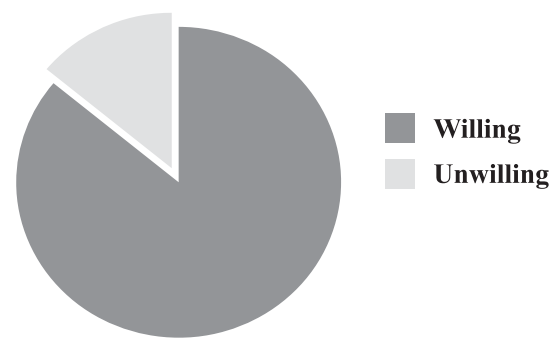

Figure 4: Farmers' willingness to plant NTFPs 
have enough land for NTFP domestication. Likewise, accessibility of road and being very near to the capital, marketing of NTFPs also may not come as a hindrance in promoting NTFPs.

In this regard, the willingness of the respondents to plant NTFPs was surveyed. 86 percent were well aware of the economic value of NTFPs and were willing to plant NTFPS where only 14 percent were unwilling to domesticate NTFPs due to the lack of landholding and human power and being not aware of the economic value of these products.

\section{Preferred Species for Domestication:}

Often farmers prefer to domesticate those species, which have higher market prices and could be harvested and sold within a short period of time. The majority of the interviewed respondents preferred to domesticate NTFPs having higher market value such as Chiraito, Kurilo, Majitho, Nigalo and Amriso. Among these species, Swertia chirayita (Chiraito) is one of them which was more preferred by the respondents due to its easiness in propagation and harvesting, relatively high market value and as the entire plant can be used for medicinal purpose.

Table 2: Preferred species for Domestication

\begin{tabular}{|c|c|c|c|}
\hline \multirow{2}{*}{ S.N } & \multirow{2}{*}{ NTFP Species } & \multicolumn{2}{|c|}{ Number of Respondents } \\
\hline & & Frequency & Percentage $(\%)$ \\
\hline 1 & \begin{tabular}{|l|} 
Chiraito \\
\end{tabular} & 12 & 40 \\
\hline 2 & Chiraito + Kurilo & 8 & 27 \\
\hline 3 & Chiraito + Nigalo+Amliso + Bans & 7 & 24 \\
\hline 4 & Chiraito + Kurilo + Majitho & 2 & 6 \\
\hline 5 & Chiraito + Kurilo + Nigalo + Amriso + Bans & 1 & 3 \\
\hline
\end{tabular}

Source: Field survey, 2009

\section{CONCLUSION AND RECOMMENDATION}

From the overall analysis of the study, it is clearly indicated that the study area has the profuse probability of promoting NTFPs for the livelihood improvement in the future days. People are becoming more and more aware about the economic importance of NTFPs. But mainly due to the lack of technical knowledge and institutional support, they are not taking NTFPs as their main occupation. Though the users have positive attitude towards NTFPs, due to the inadequate technical as well as institutional support, NTFP domestication has not been gaining popularity as it should be. Government programs for NTFPs domestication have not been reached to the local level. In the study area, Kaule .V has been playing a crucial role in motivating the users to develop modern and scientific farming system instead of traditional terrace system which include cultivation of cereal crops along with other agricultural crops and variety of trees and NTFPs. Thus, people are slowly shifting their attitude towards NTFPs domestication along with the agricultural crops which could help them in their economic stability through the generation of income and employment. 
As the critical and analytical study realizes various problems and constraints on promoting NTFPs, different recommendations are suggested to the various levels like local people, CFUG, DFO so as to gain the optimum benefit from the NTFPs:

- Incorporate NTFPs as an integral part of C.F management to support the rural livelihood improvement..

- Exploration and utilization of indigenous knowledge for the integration of NTFPs in AF system to utilize terrace ridges, kharbari and gullies for productive purposes.

- Raise more and more awareness towards NTFPs domestication in the private land to uplift the economic status of the people by convincing them towards growing NTFPs along with other agricultural crops.

- Co ordination with other stakeholders and concerned authorities related to NTFPs promotion in the user level.

- Promote the establishment of small scale NTFPs enterprise at local level that will create rural employment and generate income.

- Strengthen the capacity of the local line agencies and DFO.

- Provide adequate training and conservation education including exposure visits to enhance the knowledge on NTFPs domestication with technical co operation of various related stakeholders.

- Initiate the networking between surrounding C.F to ensure effective marketing of NTFPs.

- Marketing of NTFPs should be done through co- operatives and CFUG themselves and should provide credit facilities for processing and cultivation of NTFPs in the future.

- Ensure equitable distribution of profit and benefit to all the users focusing Dalits and females.

- Effective monitoring and supervision mechanism by DFO is necessary.

- Provision should be made to allow the sale of all kinds of NTFPs from private farmland without any legal hurdles.

- Improvement in forest laws and formulation of NTFPs promotion policies has become a necessity.

- Further research should be conducted in the other parts of the country regarding the promotion of the NTFPs. 


\section{REFERENCES}

Amatya, S.M. and Shrestha, K.R. 2002. Nepal Forestry Handbook: Nepal Forestry Association, Kathmandu.

Arnold, J.E.M. and Perez, M.R. 1998. The role of non-timber forest products in conservation and development. In: Wollenberg, E., Ingles, A. Incomes from the Forest: Methods for the Development and Conservation of Forest Products for Local Communities. IUCN andCenter for International Forestry Research, Bogor, Indonesia.

Bhattarai, D. 2001. Jaributimanjari. Lalitpur, Nakabhill,Kathmandu: Shubash Printing Press.

Chandrasekharan, D.1998. NTFP, institutions, and income generation in Nepal, lessons from community forestry. ICIMOD, Discussion Paper Series No MNR 98/1, pp.1-48.

De Beer, J.H. and McDermott, M.J. 1996. The Economic Value of NTFPs in South East Asia. The world Conservation Union ( IUCN)

Edward, D. M. 1996. Non-Timber Forest Products from Nepal: Aspects of the trade in medicinal and aromatic plants. FORESC occasional paper 2/93. Ministry of Forest and Soil conservation. Forest Research and Survey center. Kathmandu, Nepal.

Edwards, D.M. 1996a. Non-Timber Forest Products from Nepal: Aspects of the Trade in Medicinal and Aromatic Plants. FORESC Occasional Paper 2/93. Ministry of Forests and Soil Conservation. Forest research and Survey Centre. Kathmandu, Nepal.

Gautam, D.K.1999. Promoting non-timber forest products in the hills of Nepal: A case study of Jethal and Attarpur village of Sindhupalchowk District, Nepal. Master thesis, Asian Institute of Technology, Bangkok Thailand.

HMG/N. 1999. Forest resources of Nepal. Department of Forest Research and Survey, Ministry of Forests and Soil Conservation, Publication No. 74, His Majesty's of Government of Nepal, Kathmandu.

HMG/N. 1988. Master Plan for Forestry Sector. Main Report, Ministry of Forest and Soil Conservation, Nepal.

Neupane, R. P. 2000. Prospects of Agro-forestry Promotion in Hills of Nepal. Ph. D. Thesis. Dissertation, Asian Institute of Technology, Bangkok, Thailand.

Pandit, B. H. 2001. Non-timber forest products in shifting cultivation plots: a means of improving livelihood of Chepang hill tribes in the mountains of Nepal. Asia Pacific Journal of Rural Develoment, 11 (1): 1-14.

Pandit, B.H. and Thapa, G.B. 2004. Poverty and Resource Degradation in the Mountains of Nepal. Society and Natural Resources, 17: 1-16.

Pandit, B. H. 2003. Prospects of promoting non- timber Forest Products in the mountains of Nepal: A case study of Malekhu Khola watershed of Dhading district, Nepal. Master thesis, Asian Institute of Technology, Bangkok Thailand

Subedi, B.P. 2003. Non-timber forest products sub-sector in Nepal: Opportunities and challenges for linking business with biodiversity conservation. The Nepal Journal of Forestry, XII (2): 18-32 